\title{
Pengaruh Kualitas Kehidupan Kerja terhadap Kinerja Pegawai pada Dinas Pemuda dan Olahraga Kabupaten Batanghari
}

\author{
Neng Setiawati ${ }^{1}$, Satya Wahyudi ${ }^{2}$ \\ 1,2, Dosen STIE Graha Karya Muara Bulian \\ Correspondence email: n_setiawati@yahoo.co.id
}

\begin{abstract}
This study aims to provide information related to the Quality of Work Life on Employee Performance. Quality of Work Life is a problem that can not be underestimated, because it will affect the Employee Performance in achieving organizational goals. Achievement of organizational goals tends to decline is allegedly associated with work morale that is also unstable. This research is aimed to find out how big influence of Quality of Work Life to Employee Performance at Dinas Pemuda dan Olahraga Kabupaten Batang Hari Regency either arsial or simultaneously. The method used in this study is descriptive and verifikatif with independent variables (Work Life Quality) and the dependent variable (Employee Performance). The unit of analysis of this study is all employees of the Dinas Pemuda dan Olahraga Kabupaten Batang Hari Regency, the sample in this study amounted to 38 employees, taken with the technique of withdrawal Proportional random sampling. Test data analysis using Path Analysis (Path Analysis) with the help of SPSS 20.0 for windows program. The Application of Quality of Work Life has been very well implemented, Morale looks increasing in both criteria and Employee Performance is included in the criteria very well. The results showed that the Quality of Work Life directly affects Employee Performance of $8.5 \%$.
\end{abstract}

Keywords: Quality of Work Life and Employee Performance.

\section{PENDAHULUAN}

Dalam era globalisasi dan tuntutan kerja yang semakin komplek, mendorong setiap organisasi untuk terus berinovasi dan meningkatkan pengetahuan, kemampuan dan ketrampilan sumberdaya manusia yang dimilikinya sehingga mampu meningkatkan produktivitasnya. Hal ini akan sangat berdampak pada ritme kegiatan yang ada didalam organisasi yang bersangkutan. Namun demikian sebuah organisasi juga dituntut untuk dapat menciptakan suatu rasa aman dan nyaman serta kepuasan kerja pegawainya atau yang sering disebut dengan kualitas kehidupan kerja.

Kualitas kehidupan kerja atau Quality of Work Life (QWL) merupakan isu menarik yang menjadi tantangan bagi organisasi dalam penataan lingkungan kerjanya. Menurut Gary Dessler (2006) bahwa kualitas kehidupan kerja merupakan suatu keadaan dimana para pegawai dapat memenuhi kebutuhan mereka yang penting dengan bekerja dalam organisasi. Sedangkan Wayne F Cascio (1998) menyatakan bahwa kualitas kehidupan kerja merupakan persepsi pegawai bahwa mereka merasa aman, secara relatif merasa puas dan dapat berkembang sebagai manusia seutuhnya. Kualitas kehidupan kerja telah memberikan harapan terhadap kepuasan pekerja mengenai kebutuhan-kebutuhan personil melalui pengkayaan pengalaman dalam organisasi (Sumarsono, 2004). Pada sisi yang lain Siagian (2007) menyatakan bahwa kualitas kehidupan kerja merupakan upaya yang sistematik dalam kehidupan organisasional melalui cara dimana para karyawan diberi kesempatan untuk turut berperan menentukan cara mereka bekerja dan sumbangan yang mereka berikan kepada organisasi dalam rangka pencapaian dan berbagai sasarannya.
Pada dasarnya konsep dari kualitas kehidupan kerja adalah ungkapan pentingnya sebuah penghargaan terhadap manusia dalam menjalankan aktivitas dilingkungan kerjanya. Karena kualitas kehidupan kerja akan menghasilkan lingkungan kerja yang lebih manusiawi dan berupaya memenuhi semua kebutuhan anggota organisasi. Kehidupan kerja yang menyenangkan, menciptakan sikap yang positif dan memberi dorongan untuk bekerja dengan lebih tekun dan lebih baik. Sebaliknya, jika situasi kehidupan kerja tidak menyenangkan akan menimbulkan ketidakpuasan yang dapat menghilangkan motivasi kerja seseorang.

Aspek kualitas kehidupan kerja menurut Nawawi (2005) terbagi atas 9 (sembilan) aspek yaitu:

a. Di lingkungan setiap dan semua perusahaan, pegawai sebagai SDM memerlukan komunikasi yang terbuka dalam batas-batas wewenang dan tanggung jawab masing-masing.

b. Di lingkungan suatu perusahaan, setiap dan semua pekerja memerlukan pemberian kesempatan pemecahan konflik dengan perusahaan atau sesama pegawai secara terbuka, jujur dan adil.

c. Di lingkungan suatu perusahaan, setiap dan semua pegawai memerlukan kejelasan pengembangan karir masing-masing dalam menghadapi masa depannya.

d. Di lingkungan perusahaan, pegawai perlu diikutsertakan dalam pengambilan keputusan dan pelaksanaan pekerjaan, sesuai dengan posisi, kewenangan dan jabatan masin-masing.

e. Di lingkungan suatu perusahaan, setiap pegawai perlu dibina dan dikembangkan perasaan bangganya pada tempat kerja, termasuk juga pada pekerjaan atau jabatannya. 
f. Di lingkungan suatu perusahaan, setiap dan semua pegawai harus memperoleh kompensasi yang adil/wajar dan mencukupi.

g. Di lingkungan suatu perusahaan, setiap dan semua pegawai memerlukan keamanan lingkungan kerja.

h. Di lingkungan suatu perusahaan, setiap dan semua pegawai memerlukan rasa aman atau jaminan kelangsungan pekerjaannya.

i. Di lingkungan suatu perusahaan, setiap dan semua pegawai memerlukan perhatian terhadap pemeliharaan kesehatannya, agar dapat bekerja secara efektif, efesien dan produktif.

Pada umumnya kualitas kehidupan kerja mencoba memotivasi karyawan dalam hal perasaan aman, keseimbangan, harga diri, demokrasi keluarga, kepemilikan, otonomi, tanggung jawab dan fleksibilitas (Russel 1998). Peran penting kualitas kehidupan kerja adalah mengubah iklim kerja organisasi secara teknis dan manusiawi, dapat membawa kepada kualitas kehidupan kerja yang lebih baik. Peningkatan kualitas kehidupan kerja ini diperlukan untuk menciptakan kepuasan kerja sebagai pemicu semangat kerja. Aspekaspek untuk meningkatkan kualitas kehidupan kerja menurut Walton (1975) yaitu: kompensasi yang mencukupi dan adil, kondisi-kondisi kerja yang aman dan sehat, kesempatan untuk mengembangkan dan menggunakan kapasitas manusia, peluang untuk pertumbuhan dan mendapatkan jaminan, integrasi sosial dalam organisasi pekerjaan, hak-hak pegawai, pekerja dan ruang hidup secara keseluruhan, serta tanggung jawab sosial organisasi.

Kualitas kehidupan kerja atau Quality of Work Life $(Q W L)$ difokuskan pada anggota organisasi tingkat rendah yaitu mereka yang melakukan berbagai kegiatan yang bersifat teknikal dan operasional, karena pada dasarnya usaha untuk meningkatkan kualitas kehidupan kerja tidak hanya bagaimana anggota organisasi melakukan pekerjaan dengan lebih baik melainkan juga bagaimana pekerjaan dapat membuat anggota organisasi menjadi lebih baik.

Organisasi Perangkat Daerah (OPD) Pemerintahan dari suatu negara yang diatur berdasarkan peraturan perundang-undangan. Salah satu organisasi perangkat daerah Dinas Pemuda dan Olahraga Kabupaten Batang Hari di tugas untuk membantu Kepala Daerah dalam menjalan tugas dalam pembangunan di bidang Kepemudaan, Keolahragaan dan Kepariwisataan. Dinas Pemuda dan Olahraga dibentuk dengan Peraturan Daerah Kabupaten Batang Hari Nomor 11 Tahun 2016 tentang Pembentukan dan Susunan Perangkat Daerah dan Peraturan Bupati Batang Hari Nomor 41 Tahun 2016 tentang Kedudukan, Tugas dan Fungsi Susunan Organisasi dan Tata Kerja Dinas Pemuda dan Olahraga Kabupaten Batang Hari.

Berkaitan dengan kualitas kehidupan kerja di Dinas Pemuda dan Olahraga Kabupaten Batang Hari, masih terdapat beberapa ASN yang mengungkapkan sedikit permasalahan yang berkaitan dengan penghargaan diri dan lingkungan tempat bekerja serta kesempatan untuk meningkatkan kompetensinya melalui pendidikan dan pelatihan sehingga bardampak pada kualitas kehidupan kerja pegawai. Karena sebagaimana diatur dalam Peraturan Pemerintah Nomor 53 Tahun 2010 pasal 3 butir 16 menyatakan bahwa "Setiap pegawai negeri memiliki peluang yang sama dalam pengembangan karir".

Lingkungan kerja yang harmonis secara psikologis akan memberikan dukungan terhadap pegawai dalam meningkatkan produktifitas kerjanya dan mendorong keinginan untuk meningkatkan motivasi kerjanya.

\section{METODE \\ Lokasi dan Objek Penelitian}

Dinas Pemuda dan Olahraga Kabupaten Batang Hari menjadi lokasi dalam penelitian ini dengan objek penelitiannya ASN pada instansi tersebut. Dengan menggunakan 38 ASN sebagai responden dari populasi yang dijadikan sebagai objek dalam penelitian ini, yang menggambarkan karakteristik berdasarkan jenis kelamin, usia, dan pekerjaan. Menurut Ferdinand (2006) populasi merupakan gabungan dari seluruh elemen yang berbentuk peristiwa, hal atau orang yang memiliki karakteristik yang serupa yang menjadi pusat perhatian seorang peneliti karena itu dipandang sebagai sebuah semesta penelitian. Pemilihan lokasi dan objek penelitian dikarenakan diperoleh data tentang kualitas kehidupan kerja dan pengaruhnya terhadap kinerja pegawai pada Dinas Pemuda dan Olahraga Kabupaten Batang Hari.

Dalam penelitian ini metode yang digunakan bersifat deskriftif kuantitatif.

\section{Alat Analisis Data}

\section{Uji Validitas}

Uji validitas merupakan instrumen yang menggambarkan tingkat kemampuan alat ukur yang digunakan untuk mengungkapkan sesuatu yang menjadi sasaran pokok pengukuran. Uji validitas dalam penelitian ini digunakan untuk menguji validitas variabel Kualitas Kehidupan Kerja (X) terhadap Kinerja Pegawai (Y). Validitas menunjukkan sejauh mana ketepatan dan kecermatan suatu alat ukur dalam melakukan fungsi alat ukurnya (Sarwono, 2006).

Kriteria uji t dalam pengambilan keputusan adalah jika $r_{\text {hitung }}>r_{\text {tabel }}$ maka dinyatakan valid dan jika $r_{\text {hitung }}<$ $\mathrm{r}_{\text {tabel }}$ maka dinyatakan tidak valid.

\section{Uji Reliabilitas}

Uji reliabilitas merupakan instrumen yang menggambarkan pada kemantapan dan keajegan alat ukur yang digunakan. Suatu konstruk atau variabel 
dikatakan reliabel jika memberikan nilai cronbach alpha > 0,60 (Ghozali, 2005). Sehingga kriteria dari uji reliabilitas ini adalah:

a. Apabila hasil Cronbach's Alpha $>$ dari tarif signifikan 0,6 maka variabel tersebut $=$ Raliable.

b. Apabila hasil Cronbech's Alpha $<$ dari tarif signifikan 0,6 maka variabel tersebut $\neq$ Raliable.

\section{Regresi Linier}

Analisis regresi linier adalah hubungan secara linear antara variabel independen (X) dengan variabel dependen (Y). Analisis ini untuk mengetahui arah hubungan antara variabel independen dengan variabel dependen apakah positif atau negatif dan untuk memprediksi nilai dari variabel dependen apabila nilai variabel independen mengalami kenaikan atau penurunan. Data yang digunakan biasanya berskala interval atau rasio.

Rumus regresi linear sederhana sebagi berikut:

$\mathrm{Y}^{\prime}=\mathrm{a}+\mathrm{bX}$

Keterangan:

$\mathrm{Y}^{\prime}=$ Variabel dependen (nilai yang diprediksikan)

$\mathrm{X}=$ Variabel independen

$\mathrm{a}=$ Konstanta (nilai $\mathrm{Y}$ apabila $\mathrm{X}=0$ )

$\mathrm{b}=$ Koefisien regresi (nilai peningkatan ataupun penurunan)

\section{Metode t-test (uji-t)}

Uji t merupaka metode untuk menguji koefesien regresi secara individu yaitu antara variabel independen dengan variabel dependen. Tujuan dari uji $t$ ini adalah untuk:

a. Menentukan Hipotesis

$\mathrm{H}_{0}: \mathrm{b}_{1}=0$, (tidak ada pengaruh yang signifikan antara variabel independen (X) terhadap variabel dependen (Y).

$\mathrm{H}_{1}: \mathrm{b}_{1} \# 0$, (ada pengaruh yang signifikan antara variabel independen $(\mathrm{X})$ terhadap variabel dependen (Y).

b. Menetukan tingkat signifikan

Diuji dengan tingkat signifikan sebesar 0,06.

c. Kriteria pengujian

$\mathrm{H}_{0}$ diterima apabila $\mathrm{t}_{\text {tabel }}<\mathrm{t}_{\text {hitung }}$ atau $\mathrm{t}_{\text {hitung }}>\mathrm{t}_{\text {tabel }}$

$\mathrm{H}_{0}$ ditolak apabila $\mathrm{t}_{\text {hitung }}<\mathrm{t}_{\text {tabel }}$ atau $\mathrm{t}_{\text {tebel }}>\mathrm{t}_{\text {hitung }}$

\section{Koefesien Determinasi $\left(R^{2}\right)$}

Koefesien determinasi bertujuan untuk mengukur seberapa jauh kemampuan model dalam menerangkan variabel-variabel independen memberikan hampir semua informasi yang dibutuhkan untuk memprediksi variabel dependen. Penggunaan $\mathrm{R}$ square adalah bisa terhadap jumlah variabel independen yang dimasukkan kedalam model.
Untuk mendukung penilaian-penilaian yang dilakukan dalam penilitian ini digunakan indikator ukur Skala Likert, yang memiliki lima tingkat preferensi jawaban dengan nilai skor 1-5 dengan indikator Sangat Tidak Setuju sampai dengan Sangat Setuju. Menurut Sugiyono (2014) Skala Likert digunakan untuk mengukur sikap, pendapat, dan persepsi seseorang atau sekelompok orang tentang fenomena sosial.

\section{HASIL DAN PEMBAHASAN \\ Kualitas Kehidupan Kerja Pada Dinas Pemuda dan Olahraga Kabupaten Batang Hari}

Berdasarkan hasil penelitian yang dilakukan dapat dijelaskan, bahwa untuk mendukung dan memberikan hasil yang valid dan reliabel untuk mengukur faktor kualitas kehidupan kerja terhadap kinerja pegawai pada Dinas Pemuda dan Olahraga Kabupaten Batang Hari, maka responden dalam penelitian ini dapat dikelompokkan kedalam beberapa kategori sebagai berikut:

Responden dilihat dari Usia

Tabel 1. Responden Menurut Kategori Usia

\begin{tabular}{cccc}
\hline No. & Kategori & Jumlah & Persentase $(\%)$ \\
\hline 1 & $<30$ tahun & 2 & 5,26 \\
2 & $31-40$ tahun & 10 & 26,32 \\
3 & $41-50$ tahun & 14 & 36,84 \\
4 & $>51$ tahun & 12 & 31,38 \\
& & 38 & 100,00 \\
\hline
\end{tabular}

Sumber : Data primer yang diolah

Dari tabel diatas dapat diketahui bahwa usia reponden terbanyak adalah 41-50 tahun sebanyak 14 orang responden atau sebesar $36,84 \%$. Kemudian $<30$ tahun sebanyak 2 orang atau sebesar $5,26 \%$, untuk usia $31-40$ tahun sebanyak 10 orang atau sebesar $26,32 \%$, dan selanjutnya untuk usia > 51 tahun sebanyak 12 orang atau sebesar $31,38 \%$.

\section{Responden dilihat dari Jenis Kelamin}

Tabel 2. Responden Menurut Kategori Jenis Kelamin

\begin{tabular}{cccc}
\hline No. & Kategori & Jumlah & Persentase (\%) \\
\hline 1 & Pria & 26 & 68,42 \\
2 & Wanita & 12 & 31,58 \\
& & 38 & 100,00 \\
\hline
\end{tabular}

Sumber : Data primer yang diolah

Dari tabel diatas dapat diketahui bahwa jumlah jenis kelamin reponden terbanyak adalah pria sebanyak 26 orang atau sebesar $68,42 \%$. Sedangkan jenis kelamin wanita sebanyak 12 orang atau sebesar $31,58 \%$.

\section{Responden dilihat dari Pendidikan}


Neng Setiawati dan Satya Wahyudi, Pengaruh Kualitas Kehidupan Kerja terhadap Kinerja Pegawai pada Dinas Pemuda dan Olahraga Kabupaten Batanghari

Tabel 3. Reponden Menurut Kategori Pendidikan

\begin{tabular}{cccc}
\hline No. & Kategori & Jumlah & Persentase (\%) \\
\hline 1 & SMA & 10 & 26,32 \\
2 & Diploma 3 (D III) & 1 & 2,63 \\
3 & Sarjana (S1) & 23 & 60,53 \\
4 & Pasca Sarjana (S2) & 4 & 10,53 \\
& & 38 & 100,00 \\
\hline
\end{tabular}

Sumber : Data primer yang diolah

Dari tabel diatas dapat diketahui bahwa kategori pendidikan terbanyak adalah sarjana (S1) sebanyak 23 orang responden atau 60,53\%, untuk kategori SMA sebanyak 10 orang atau sebesar $26,32 \%$, kemudian untuk kategori Diploma 3 (D-III) sebanyak 1 orang atau sebesar 2,63\% dan sedangkan untuk kategori Pasca Sarjana (S2) sebanyak 4 orang atau sebesar $10,53 \%$.

\section{Responden dilihat dari Pengkat / Golongan}

Tabel 4. Reponden Menurut Kategori Pangkat / Golongan

\begin{tabular}{cccc}
\hline No. & Kategori & Jumlah & Persentase (\%) \\
\hline 1 & Golongan I & 0 & 0,00 \\
2 & Golongan II & 7 & 18,42 \\
3 & Golongan III & 24 & 63,16 \\
4 & Golongan IV & 7 & 18,42 \\
& & 38 & 100,00 \\
\hline
\end{tabular}

Sumber : Data primer yang diolah

Dari tebel diatas dapat diketahui bahwa menurut kategori pangkat / golongan tebanyak adalah Golongan III sebanyak 24 orang atau sebesar $63,16 \%$, untuk kategori Golongan I tidak ada. Sedangkan Golongan II sebanyak 7 orang atau sebesar $18,42 \%$ dan untuk kategori Golongan IV sebanyak 7 orang atau sebesar $18,42 \%$.

\section{Kualitas Kehidupan Kerja}

Dari hasil oleh kuisioner penelitian yang disampaikan kepada responden berkaitan dengan kualitas kehidupan kerja yang ada di lingkungan kerjanya, maka diperoleh hasil sebagai berikut:

Tabel 5. Pendapat Responden Terhadap Kualitas Kehidupan Kerja di Dinas Pemuda dan Olahraga Kabupaten Batang Hari

\begin{tabular}{|c|c|c|c|c|c|c|c|c|c|c|c|c|c|}
\hline \multirow{2}{*}{ No } & \multirow{2}{*}{ Pertanyaan } & \multicolumn{2}{|c|}{ STS } & \multicolumn{2}{|c|}{ TS } & \multicolumn{2}{|c|}{$\mathbf{N}$} & \multicolumn{2}{|c|}{$\mathbf{S}$} & \multicolumn{2}{|c|}{ SS } & \multirow{2}{*}{$\Sigma$} & \multirow{2}{*}{ Indeks } \\
\hline & & $\mathrm{Jml}$ & Skor & $\mathrm{Jml}$ & Skor & $\mathrm{Jml}$ & Skor & $\mathrm{Jml}$ & Skor & $\mathrm{Jml}$ & Skor & & \\
\hline 1 & $\begin{array}{l}\text { Kompensasi yang di berikan Pemerintah sudah } \\
\text { mencukupi untuk memenuhi kebutuhan hidup para } \\
\text { pegawai. }\end{array}$ & & & & & 1 & 3 & 31 & 124 & 6 & 30 & 157 & 4,1 \\
\hline 2 & $\begin{array}{l}\text { Organisasi memfasilitasi kondisi kerja yang aman } \\
\text { dan sehat demi kelancaran dalam bekerja. }\end{array}$ & & & & & 2 & 6 & 23 & 92 & 13 & 65 & 163 & 4,3 \\
\hline 3 & $\begin{array}{l}\text { Organisasi memberikan kesempatan kepada } \\
\text { pegawai untuk mengembangkan kemampuan dan } \\
\text { menggunakan kapasitas manusia dalam } \\
\text { melaksanakan pekerjaan. }\end{array}$ & & & & & 7 & 21 & 23 & 92 & 8 & 40 & 153 & 4,0 \\
\hline 4 & $\begin{array}{l}\text { Pegawai diberi peluang untuk mengembangkan } \\
\text { karirnya melalui sumber daya manusia yang } \\
\text { dimiliki serta mendapatkan jaminan terhadap } \\
\text { pendapatan. }\end{array}$ & & & & & 7 & 21 & 22 & 88 & 9 & 45 & 154 & 4,1 \\
\hline 5 & $\begin{array}{l}\text { Integrasi sosial dalam organisasi pekerjaan harus } \\
\text { berjalan dengan baik agar bisa mencapai tujuan dari } \\
\text { organisasi. }\end{array}$ & & & & & 1 & 3 & 30 & 120 & 7 & 35 & 158 & 4,2 \\
\hline 6 & $\begin{array}{l}\mathrm{Di} \text { dalam organisasi hak-hak pegawai harus } \\
\text { diperhatikan karena untuk memberikan pelayanan } \\
\text { yang adil begi setiap pegawai. }\end{array}$ & & & & & 5 & 15 & 26 & 104 & 7 & 35 & 154 & 4,1 \\
\hline 7 & $\begin{array}{l}\text { Ruang kehidupan para pegawai memberikan } \\
\text { dampak positif dan negatif terhadap suatu } \\
\text { organisasi. }\end{array}$ & & & & & 3 & 9 & 29 & 116 & 6 & 30 & 155 & 4,1 \\
\hline 8 & $\begin{array}{l}\text { Organisasi mempunyai tanggung jawab sosial } \\
\text { kepada seluruh pegawai dalam menjalankan } \\
\text { pekerjaannya. }\end{array}$ & & & & & 2 & 6 & 23 & 92 & 13 & 65 & 163 & 4,3 \\
\hline 9 & $\begin{array}{l}\text { Kompensasi diberikan secara adil dan merata } \\
\text { kepada para pegawai. }\end{array}$ & & & & & 1 & 3 & 31 & 124 & 6 & 30 & 157 & 4,1 \\
\hline & Rata-rata Indeks & & & & & & & & & & & 1.414 & 4,1 \\
\hline
\end{tabular}

Sumber : Data primer yang diolah

Dengan indeks tertinggi sebesar 4,3 dan indeks terendah adalah 4,0, sedangkan rata-rata indesk skornya adalah 4,1 yang artinya respon atau tanggapan variabel kualitas kehidupan kerja adalah baik. Pada variabel kualitas kehidupan kerja pernyataan kuesioner nomor 2 dan 8 yakni "Organisasi memfasilitasi kondisi-kondisi kerja yang aman dan sehat" dan "Organisasi mempunyai tanggung jawab sosial kepada seluruh pegawai dalam menjalankan pekerjaannya" memberikan tanggapan yang sangat dominan terhadap kualitas kehidupan kerja pada Dinas Pemuda dan Olahraga Kabupaten Batang Hari.

\section{Kinerja Pegawai}

Dalam suatu organisasi setiap pegawai mempunyai hasil kinerja yang berbeda-beda anatara invidu dalam menyelesaiakan suatu pekerjaan. Dan setiap pegawai juga mempunyai kemampuan, semangat 
dan loyalitas terhadap pekerjaan juga berbeda. Untuk itu kinerja pegawai sangatlah menentukan suatu keberhasilan dari setiap organisasi dalam mencapai tujuannya ataupun memberikan pelayanan baik.

Kemudian organisasi perangkat daerah kabupaten batang hari khususnya dinas pemuda dan olahraga kabupaten batang hari ingin mengetahui sejauh mana hasil pelayanan yang telah diberikan. Dengan demikian peneliti akan melakukan penelitian akan menyebar kuesioner sebagai tolak ukur untuk mengetahui tanggapan responden terhadap kinerja pegawai dan dapat dilihat pada tabel 6 sebagai berikut :

Tabel 6. Tanggapan Responden Terhadap Kinerja Pegawai Pada Dinas Pemuda dan Olahraga Kabupaten Batang Hari

\begin{tabular}{|c|c|c|c|c|c|c|c|c|c|c|c|c|c|}
\hline \multirow{2}{*}{ No } & \multirow{2}{*}{ Pertanyaan } & \multicolumn{2}{|c|}{ STS } & \multicolumn{2}{|c|}{ TS } & \multicolumn{2}{|c|}{$\mathbf{N}$} & \multicolumn{2}{|c|}{$\mathbf{S}$} & \multicolumn{2}{|c|}{ SS } & \multirow[b]{2}{*}{$\sum$} & \multirow{2}{*}{ Indeks } \\
\hline & & $\mathrm{Jml}$ & Skor & $\mathrm{Jml}$ & Skor & $\mathrm{Jml}$ & Skor & $\mathrm{Jml}$ & Skor & $\mathrm{Jml}$ & Skor & & \\
\hline 1 & $\begin{array}{l}\text { Rasa kesetiaan terhadap pimpinan dan } \\
\text { organisasi harus ditanamkan pada setiap } \\
\text { pribadi pegawai. }\end{array}$ & & & & & 6 & 18 & 24 & 96 & 8 & 40 & 154 & 4,1 \\
\hline 2 & $\begin{array}{l}\text { Setiap pegawai mampu memberikan } \\
\text { hasil kerja yang baik bagi organisasi. }\end{array}$ & & & & & 1 & 3 & 21 & 84 & 16 & 80 & 167 & 4,4 \\
\hline 3 & $\begin{array}{l}\text { Dalam menjalankan pekerjaan pegawai } \\
\text { harus memiliki sikap jujur kepada } \\
\text { organisasi maupun dengan diri sendiri. } \\
\text { Pegawai datang dan pulang keria sesuai }\end{array}$ & & & & & 6 & 18 & 24 & 96 & 8 & 40 & 154 & 4,1 \\
\hline 4 & $\begin{array}{l}\text { Pegawai datang dan pulang kerja sesuai } \\
\text { dengan waktu yang sudah ditetapkan } \\
\text { oleh organisasi. }\end{array}$ & & & & & 5 & 15 & 24 & 96 & 9 & 45 & 156 & 4,1 \\
\hline 5 & $\begin{array}{l}\text { Setiap pegawai harus kreativitas dalam } \\
\text { menyelesaikan pekerjaannya. }\end{array}$ & & & & & 6 & 18 & 23 & 92 & 9 & 45 & 155 & 4,1 \\
\hline 6 & 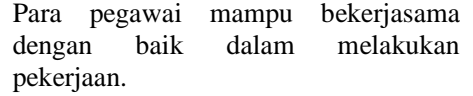 & & & & & 3 & 9 & 21 & 84 & 14 & 70 & 163 & 4,3 \\
\hline 7 & $\begin{array}{l}\text { Pemimpin memiliki hubungan baik } \\
\text { dengan setiap pegawai. }\end{array}$ & & & & & 3 & 9 & 27 & 108 & 8 & 40 & 157 & 4,1 \\
\hline 8 & $\begin{array}{l}\text { Kepribadian seorang pegawai yang baik } \\
\text { dapat meningkatkan hasil pekerjaan dan } \\
\text { pelayanan kepada masyarakat. } \\
\text { Semua pegawai dapat mempertanggung }\end{array}$ & & & & & 1 & 3 & 25 & 100 & 12 & 60 & 163 & 4,3 \\
\hline 9 & $\begin{array}{l}\text { jawabkan pekerjaan yang berikan } \\
\text { kepadanya. }\end{array}$ & & & & & 4 & 12 & 16 & 64 & 18 & 90 & 166 & 4,4 \\
\hline & Rata-rata Indeks & & & & & & & & & & & 1.435 & 4,2 \\
\hline
\end{tabular}

Sumber : Data primer yang diolah

Dengan indeks tertinggi adalah sebesar 4,4 dan indeks terendah adalah 4,1, sedangkan rata-rata indeks skornya sebesar 4,2 yang artinya respon atau tanggapan responden terhadap variabel kinerja pegawai adalah baik. Pada variabel kinerja pegawai secara rata-rata berdasarkan data hasil kuesioner yang dilakukan pada responden memberikan respon yang baik terhadap kinerja pegawai.

\section{Pengaruh Kualitas Kehidupan Kerja Terhadap Kinerja Pegawai}

Untuk mengetahui besarnya pengaruh kualitas kehidupan kerja terhadap kinerja pegawai pada Dinas Pemuda dan Olahraga Kabupaten Batang Hari digunakan alat analisis persamaan regresi linear sederhana, pengujian hipotesis melalui uji $\mathrm{t}$ dan koefesien determinasi. Data dioleh dengan bantuan komputer yaitu dengan menggunakan program SPSS versi 20.0.

\section{Uji Validitas}

Uji Validitas digunakan untuk mengukur sah atau tidaknya suatu kuesioner. Dasar pengambilan keputusan yang digunakan adalah melakukan uji signifikasi dengan membandingkan nilai $r$ hitung dengan $r$ tabrl. Untuk sampel sebanyak 38 orang maka $r$ tabel adalah 0,2638. Maka hasil analisisnya adalah sebagai berikut :

Tabel 7. Uji Validitas

\begin{tabular}{|c|c|c|c|c|}
\hline No. & Indikator & r hitung & $r$ tabel & Ket \\
\hline$(\mathbf{X})$ & Kualitas Kehidupan Kerja & & & \\
\hline 1 & $\begin{array}{l}\text { Kompensasi yang di berikan Pemerintah sudah mencukupi untuk memenuhi kebutuhan } \\
\text { hidup para pegawai. }\end{array}$ & 0,597 & 0,2638 & Valid \\
\hline 2 & $\begin{array}{l}\text { Organisasi memfasilitasi kondisi-kondisi kerja yang aman dan sehat demi kelancaran } \\
\text { dalam bekerja. }\end{array}$ & 0,603 & 0,2638 & Valid \\
\hline 3 & $\begin{array}{l}\text { Organisasi memberikan kesempatan kepada pegawai untuk mengembangkan } \\
\text { kemampuan dan menggunakan kapasitas manusia dalam melaksanakan pekerjaan. }\end{array}$ & 0,527 & 0,2638 & Valid \\
\hline 4 & $\begin{array}{l}\text { Pegawai diberi peluang untuk mengembangkan karirnya melalui sumber daya manusia } \\
\text { yang dimiliki serta mendapatkan jaminan terhadap pendapatan. }\end{array}$ & 0,597 & 0,2638 & Valid \\
\hline 5 & $\begin{array}{l}\text { Integrasi sosial dalam organisasi pekerjaan harus berjalan dengan baik agar bisa } \\
\text { mencapai tujuan dari organisasi. }\end{array}$ & 0,527 & 0,2638 & Valid \\
\hline
\end{tabular}


6 Di dalam organisasi hak-hak pegawai harus diperhatikan karena untuk memberikan pelayanan yang adil begi setiap pegawai.

$7 \quad$ Ruang kehidupan para pegawai memberikan dampak positif dan negatif terhadap suatu organisasi.

8 Organisasi mempunyai tanggung jawab sosial kepada seluruh pegawai dalam menjalankan pekerjaannya.

9 Kompensasi diberikan secara adil dan merata kepada para pegawai.

(Y) Kinerja Pegawai

1 Rasa kesetian terhadap pimpinan dan organisasi harus ditanamkan pada setiap pribadi pegawai.

2 Setiap pegawai mampu memberikan hasil kerja yang baik bagi organisasi.

3 Dalam menjalankan pekerjaan pegawai harus memiliki sikap jujur kepada organisasi maupun dengan diri sendiri.

4 Pegawai datang dan pulang kerja sesuai dengan waktu yang sudah ditetapkan oleh organisasi.

5 Setiap pegawai harus kreativitas dalam menyelesaikan pekerjaannya.

$0,603 \quad 0,2638 \quad$ Valid

$0,527 \quad 0,2638 \quad$ Valid

$0,597 \quad 0,2638 \quad$ Valid

$0,597 \quad 0,2638 \quad$ Valid

$0,650 \quad 0,2638 \quad$ Valid

$0,307 \quad 0,2638 \quad$ Valid

$0,435 \quad 0,2638 \quad$ Valid

$0,650 \quad 0,2638 \quad$ Valid

$0,514 \quad 0,2638 \quad$ Valid

$0,275 \quad 0,2638 \quad$ Valid

$0,650 \quad 0,2638 \quad$ Valid

7 Pemimpin memiliki hubungan baik dengan setiap pegawai.

8 Kepribadian seorang pegawai yang baik dapat meningkatkan hasil pekerjaan dan pelayanan kepada masyarakat.

9 Semua pegawai dapat mempertanggung jawabkan pekerjaan yang berikan kepadanya.

Sumber : Data primer yang diolah

Dari tabel 7 diatas dapat dijelaskan jika $\mathrm{r}_{\text {hitung }}>$ dari $\mathrm{r}$ tabel maka dapat disimpulkan bahwa semua item pertanyaan dalam indikator variabel kualitas kehidupan kerja (X) adalah semua item pertanyaan valid. Sedangkan untuk variabel kinerja pegawai $(Y)$ dapat diketahui semua item pertanyaan valid.

\section{Uji Reliabilitas}

Uji Reliabilitas digunakan untuk melihat apakah alat ukur yang digunakan (kuesioner) reabilitas suatu kuesioner terhadap penelitian. Dalam uji analisis reliabilitas, suatu variabel dinyatakan reliabel. Jika mempunyai nilai Cronbech alpha lebih besar dari 0.600 (Jonathan Sarwono : 2012). Hasil uji reliabilitas dapat dilihat dari tabel 8 berikut ini :

Tabel 8. Uji Reliabilitas

\begin{tabular}{lccc}
\hline \multicolumn{1}{c}{ Variabel } & Cronbach Alpha & Taraf Signifikan & Ket \\
\hline Kualitas Kehidupan Kerja (X) & 0,852 & 0,6 & Reliabel \\
Kinerja Pegawai (Y) & 0,796 & 0,6 & Reliabel \\
\hline
\end{tabular}

Sumber : Data primer yang diolah

Berdasarkan tabel 8 diatas dapat dijelaskan bahwa variabel kualitas kehidupan kerja $(\mathrm{X})$, diperoleh nilai cronbach alpha 0,852 dengan taraf signifikan $(0,852>$ 0,6 ), sehingga dengan demikian hasil uji reliabilitas pada variabel ini adalah reliabel.

Kemudian berdasarkan tabel 5.4 diatas juga dapat dijelaskan bahwa variabel kinerja pegawai (Y) , diperoleh nilai cronbach alpha 0,796 dengan taraf signifikan 0,6. Ini menunjukkan bahwa cronbech apla lebih besar dari taraf signifikan $(0,796>0,6)$ sehingga dengan demikian hasil dari uji reliabilitas pada variabel ini adalah reliabel.

\section{Regresi Linear Sederhana}

Untuk menganalisis pengaruh kualitas kehidupan kerja terhadap kinerja pegawai pada Dinas Pemuda dan Olahraga Kabupaten Batang Hari dilakukan pengujian dan pembuktian pengaruh tersebut digunakan analisis regresi linear sederhana. Hasil perhitungan regresi linear sewderhana dengan program SPSS versi 20.0 dari tabel koefesien diperoleh persamaan sebagai berikut :

Tabel 9. Regresi Linear Sederhana

Coefficients $^{\mathbf{a}}$

\begin{tabular}{|l|r|r|r|r|r|}
\hline \multirow{2}{*}{ Model } & \multicolumn{2}{|c|}{ Unstandardized Coefficients } & Standardized Coefficients & \\
\cline { 2 - 5 } & \multicolumn{1}{|c|}{ B } & Std. Error & Beta & \multicolumn{1}{c|}{ Sig. } \\
\hline (Constant) & 20,694 & 4,268 & 4,848 & .000 \\
KUALITAS KEHIDUPAN KERJA & .178 & .157 & .186 & 1,728 \\
\hline
\end{tabular}

a. Dependent Variable: KINERJA PEGAWAI 
$Y=20,694+0,178 x$

Dari hal diatas dapat dilihat nilai a yaitu sebesar 20,694 yang artinya bila kualitas kehidupan kerja sebesar $0(X)=0$ maka kinerja yang dicapai 20,694. Hal ini menunjukkan bahwa kualitas kehidupan kerja berpengaruh terhadap kinerja pegawai. Selain itu dapat dilihat bahwa kualitas kehidupan kerja berpengaruh bernilai positif, hal ini menunjukkan adanya hubungan positif antara kualitas kehidupan kerja terhadap kinerja pegawai.

Nilai $b=0,178$ artinya jika kualitas kehidupan kerja ditingkatkan sebesar 1 (satu) satuan, maka akan dapat meningkatkan kinerja pegawai sebesar 0,178.

Pengujian Hipotesis Melalui Uji t
Sebagai mana diterangkan bahwa pengujian hipotesis melalui Uji $\mathrm{t}$, setelah nilai $\mathrm{t}$ hitung diperoleh langkah berikutnya adalah membandingkan nilai $t$ hitung variabel bebas dengan nilai $\mathrm{t}$ tabel hipotesis tersebut. $\mathrm{H}_{0}$ ditolak $\mathrm{t}_{\text {hitung }}<\mathrm{t}$ tabel, $\mathrm{H}_{\mathrm{a}}$ diterima jika $\mathrm{t}_{\text {hitung }}>\mathrm{t}$ tabel. Berdasarkan tabel koefesien dapat diketahui bahwa nilai $\mathrm{t}_{\text {hitung }}$ sebesar 4,848 dan $\mathrm{t}$ tabel sebesar 1,688, maka nilai $\mathrm{t}$ hitung lebih besar dari $t_{\text {tabel. }}$. Jadi dapat disimpulkan bahwa variabel kualitas kehidupan kerja berpengaruh signifikan terhadap kinerja pegawai.

\section{Koefesien Determinasi $\left(R^{2}\right)$}

Analisis koefesien determinasi digunakan untuk mengetahui persentase sumbangan pengaruh variabel independent $X$ (Kualitas Kehidupan Kerja) terhadap variabel dependen Y (Kinerja Pegawai) seperti hasil pengolahan SPSS vesi 20.0 dibawah ini :

Tabel 10. Koefesien Determinasi $\left(\mathrm{R}^{2}\right)$

Model Summary

\begin{tabular}{|c|c|c|c|c|}
\hline Model & $\mathrm{R}$ & R Square & Adjusted R Square & Std. Error of the Estimate \\
\hline 1 & $.186^{\mathrm{a}}$ & .135 & .188 & 4,815 \\
\hline
\end{tabular}

a. Predictors: (Constant), KUALITAS KEHIDUPAN KERJA

Berdasarkan tabel summary diatas diperoleh nilai koefesien determinasi (r) yang diperoleh adalah sebesar 0,135 yang artinya pengaruh kualitas kehidupan kerja terhadap kinerja pegawai pada Dinas Pemuda dan Olahraga Kabupaten Batang Hari sebesar 13,5\% sedangkan sisanya sebesar $86,5 \%$ disebabkan faktor lain yang tidak termasuk dalam penelitian ini.

\section{SIMPULAN}

Dengan dilakukan penelitian yang berjudul Pengaruh Kualitas Kehidupan Kerja Terhadap Kinerja Pegawai Pada Dinas Pemuda dan Olahraga Kabupaten Batang Hari dapat disimpulkan sebagai berikut :

1. Tanggapan responden terhadap Kualitas Kehidupan Kerja di Dinas Pemuda dan Olahraga Kabupaten Batang Hari adalah baik. Hal ini ditunjukkan dari rata-rata indeks responden sebesar 4,1 yang berada pada rentang skala 3,41-4,20.

2. Kondisi kinerja pegawai pada Dinas Pemuda dan Olahraga Kabupaten Batang Hari mendapatkan respon dari responden baik, Yang ditunjukkan dari nilai rata-rata indeks sebesar 4,2 , yang berada pada rentang skala 3,41-4,20.

3. Pengaruh Kualitas Kehidupan Kerja Terhadap Kinerja Pegawai Pada Dinas Pemuda dan Olahraga Kabupaten Batang Hari dapat disimpulkan bahwa terdapat pengaruh kualitas kehidupan kerja terhadap kinerja pegawai yang terlihat pada Uji $\mathrm{t}(\mathrm{t}$ hitung 4,848 $>\mathrm{t}$ tabel 1,688) sedangkan besaran persentasenya adalah $13,5 \%$ dan sisanya ditentukan oleh variabel yang tidak diteliti.

\section{DAFTAR PUSTAKA}

Agusty, Ferdinand, 2006, Metode Penelitian Manajemen: Pedoman Penelitian untuk Skripsi, Tesis dan Disertasi Ilmu Manajemen, Semarang, Universitas Diponegoro.

Cascio, Wayne F, 1998, Managing Human Resource Productivity, Quality of Work Life Profits, (Fifth Edition), Amerika, Irwin MC, Grawhill.

Dessler, Gary, 2006, Manajemen Sumber Daya Manusia Edisi Kesepuluh Jilid I, Jakarta, PT. Indeks.

Ghozali, Imam, 2005, Aplikasi Analisis Multivariate dengan Program SPSS, Semarang, Badan Penerbit Universitas Diponegoro,

Nawawi, (2005). Manajemen Sumber Daya Manusia Untuk Bisnis yang Kompetitif .Cetakan Keempat. Penerbit Gajah Mada University Press, Yogyakarta.

Pemerintah Kabupaten Batang Hari, 2016, Peraturan Daerah Nomor 11 Tahun 2016 tentang Pembentukan dan Susunan Perangkat Daerah

Pemerintah Kabupaten batang Hari, 2016, Peraturan Bupati Batang Hari Nomor 41 Tahun 2016 tentang Kedudukan, Tugas dan Fungsi Susunan Organisasi dan Tata Kerja Dinas Pemuda dan Olahraga Kabupaten Batang Hari.

Russel, Bernadin, 1998, Human Resoursce Management, (second edition), New York, Irwin MC Grawhill.

Sarwono, Jonathan, 2006, Metode Penelitian Kuantitatif \& Kualitatif, Yogyakarta, Graha Ilmu. 
Neng Setiawati dan Satya Wahyudi, Pengaruh Kualitas Kehidupan Kerja terhadap Kinerja Pegawai pada Dinas Pemuda dan Olahraga Kabupaten Batanghari

Siagian, P. Sondang. 2007. Manajemen Sumber Daya Manusia. Jakarta. PT. Bumi Aksara.

Sugiyono. 2014. Metodologi Penelitian Pendidikan Pendekatan Kuantitatif, Kualitatif dan $R$ \& D. Bandung: Alfabeta.

Sumarsono, Sony HM, 2004, Metode Riset Sumber Daya Manusia, Yogyakarta, Graha Ilmu.

Walton, R.E, 1975, Criteria for Quality of Working Life, InL.E. Davis, A.B. Cherns and Associates (Eds) Teh Quality of Working. New York. The Free Press. 